\title{
How do microlocal environmental variations affect microbial activities of a Pinus halepensis litter in a Mediterranean coastal area?
}

\author{
Leila Qasemian, Daniel Guiral, Anne-Marie Farnet* \\ Institut Méditerranéen de Biodiversité et d'Ecologie marine et continentale (IMBE), Aix-Marseille Université, UMR CNRS, IRD, Avignon Université, Faculté de St-Jérôme,
} F-13397 Marseille Cedex 20, France

\section{H I G H L I G H T S}

- Microlocal condition effects on microbial activities were studied via litter bags.

- Microlocal conditions significantly affected activities of microorganisms.

- Microbial activities were most strongly impacted by seasonal changes.

\section{Keywords:}

Micro-climate

Litterbags

Microbial functioning

Litter enzyme activities

Osmotic stress

\begin{abstract}
A B S T R A C T
Mediterranean coastal ecosystems suffer many different types of natural and anthropogenic environmental pressure. Microbial communities, major conductors of organic matter decomposition are also subject to these environmental constraints. In this study, our aim was to understand how microbial activities vary at a small spatio-temporal scale in a Mediterranean coastal environment. Microbial activities were monitored in a Pinus halepensis litter collected from two areas, one close to $(10 \mathrm{~m})$ and one far from $(300 \mathrm{~m})$ the French Mediterranean coast. Litters were transferred from one area to the other using litterbags and studied via different microbial indicators after 2, 5 and 13 months. Microbial Basal Respiration, $\mathrm{qCO}_{2}$, certain enzyme activities (laccase, cellulase, $\beta$-glucosidase and acid phosphatase) and functional diversity via Biolog microplates were assayed in litterbags left in the area of origin as well as in litterbags transferred from one area to the other. Results highlight that microbial activities differ significantly in this short spatial scale over time. The influence of microlocal conditions more intensified for litters situated close to the sea, especially during summer seems to have a stressful effect on microbial communities, leading to less efficient functional activities. However, microbial activities were more strongly influenced by temporal variations linked to seasonality than by location.
\end{abstract}

\section{Introduction}

Litter decomposition is mainly controlled by three factors: climate, chemical quality of litter and the nature and abundance of decomposing organisms (Coûteaux et al., 1995). For example, differences in litter chemical composition lead to variability in the type and relative abundance of microbial decomposers, and thus in their activity. Microorganisms are involved in organic matter decomposition through their extracellular enzyme production, which is directly linked to environmental conditions. Mediterranean forest litter decomposition in inland areas has been well documented, particularly with respect to litter chemical composition related to plant cover and/or vegetation succession and soil degradation (Garcia et al., 2002; Francaviglia et al., 2004; Gritti et al., 2006; Kurz et al., 2000; Fioretto et al., 2007, 2009; Papa et al., 2008). However, little is known about microbial communities

\footnotetext{
* Corresponding author.

E-mail address: anne-marie.farnet@imbe.fr (A.-M. Farnet).
}

involved in litter decomposition in coastal environments exposed to osmotic stress or pollution via sea sprays in addition to drastic climate conditions (Asia et al., 2009; Yuan et al., 2007). Salinity is actually a major factor influencing microbial community structure and functions and can strongly alter organic matter turnover, especially when combined with other water potential stresses such as summer drought (Wichern et al., 2006; Setia et al., 2011). Furthermore, saline environments harbor great microbial diversity from both taxonomic and phenotypic point of view (Zahran,1997; Ayuso et al., 2011).

To better understand factors influencing coastal environment functioning at a microscale, we investigated microbial functioning in Pinus halepensis litters located close $(10 \mathrm{~m})$ to the coast and $300 \mathrm{~m}$ away. We indeed hypothesized that microbial communities differently exposed to marine influence are functionally dissimilar. Various indicators of microbial activities i.e. enzyme activities and microbial respiration were thus chosen to study microbial functioning. Moreover, functional diversity was assessed via catabolic level physiological profile, using EcoPlate. Litters of each area were transferred to the other area using 
litterbags in order to test the capacity of microbial communities to adapt to new microlocal conditions characterized by a different level of osmotic stress. Microbial activities and environmental parameters (temperature, humidity, conductivity and chloride ion concentrations) were monitored from both areas over 13 months. Thus our objectives were to study, in a Mediterranean coastal environment, i) to which extent more drastic microlocal environmental conditions (i.e. varying exposures to sea sprays, desiccation, etc.) affect microbial communities located at the coastal line and ii) whether a potential shift in microbial functions is observed when microbial communities are exposed to different environmental conditions after litter transfers.

\section{Materials and methods}

\subsection{Litter sampling}

A composite sampling was performed in April 2009 from partially degraded litter (OL) of Aleppo pine (P. halepensis L.) in two areas (200 $\mathrm{m}^{2}$ each) on the French Mediterranean coast (Massif de Marseilleveyre, Marseille) ( $\left.43^{\circ} 12^{\prime} 34^{\prime \prime} \mathrm{N}, 5^{\circ} 21^{\prime} 36^{\prime \prime} \mathrm{E}\right)$. Two areas were located at 10 and $300 \mathrm{~m}$ from the coast, respectively name C10 and C300 and three sites, separated from each other by $1 \mathrm{~km}$, were selected in each area. Randomly sampled litter (horizon L) from each area was sieved (>2 $\mathrm{mm}$ mesh size) and homogenized before being placed in litterbags. Litterbags $(20 \times 25 \mathrm{~cm}$ ) made of polypropylene ( $1 \mathrm{~mm}$ mesh size) were filled with about $40 \mathrm{~g}$ (dry weight) of the litter from each area. Twenty seven litterbags were then randomly placed in their area of origin (C10 or C300) as control ( 3 replicates $\times 3$ sites $\times 3$ sampling times), while twenty seven other litterbags were transferred from one area to the other. Litters were then characterized microbiologically (basal respirometry, microbial biomass, enzyme activities, catabolic profiles) and chemically ( $\mathrm{C} / \mathrm{N}$, solid-state NMR) after 2, 5 and 13 months in situ (to assess short-term effects, summer draught effect, and long-term effects respectively). A total of 18 litterbags were thus analyzed for each sampling time and for each area ( 9 controls and 9 exchanged litter bags). Litter mass loss was followed by weighing the litter bags at each sampling time.

\subsection{Environmental parameter measurement}

Temperature, humidity, $\mathrm{pH}$, electrical conductivity (EC) and $\mathrm{Cl}^{-}$ concentration in litters from both areas were monitored throughout the experiment at least every 2 months. Mean daily temperature was measured using a USB temperature logger (VOLTCRAFT, $100 \mathrm{~T}$ ) placed at around $4 \mathrm{~cm}$-depth at both the $\mathrm{C} 10$ and $\mathrm{C} 300$ areas. Litter extract, $1: 10 \mathrm{w} / \mathrm{v}$ (litter $/ \mathrm{H}_{2} \mathrm{O}$ ), was used for $\mathrm{pH}$ and EC using a composite sampling from each area. After a 30 min equilibrium time, $\mathrm{pH}$ was measured with Metrohm 744, electrical conductivity with DiST 3 (HANNA instruments) and chloride ion concentration with Cyberscan 510. Litter moisture was determined after drying $\left(90^{\circ} \mathrm{C}\right)$ to a constant weight. For each environmental parameter, difference between C10 and C300 was calculated over a monitoring period from March 2009 to February 2011.

\subsection{Basal and substrate induced respiration}

Microbial Basal Respiration (BR) and Substrate Induced Respiration (SIR) were measured on a $2 \mathrm{~g}$ sub-sample $(\mathrm{dw})$ from each litterbag both at the humidity of the sample and at standardized humidity at $60 \%$ as the highest humidity measurement in the field. For BR, litter was placed in glass jars $(117 \mathrm{ml})$, flushed with fresh air and closed by rubber septum before incubation at $25{ }^{\circ} \mathrm{C}$ for $4 \mathrm{~h}$. The concentration of the $\mathrm{CO}_{2}$ produced was measured at the end of incubation by injecting one milliliter of the jar headspace gas into a gas chromatograph (Chrompack CHROM 3-CP 9001), equipped with a thermal conductivity detector and a fused silica capillary column $(10 \mathrm{~m} \times 0.53 \mathrm{~mm})$. SIR was measured like BR, glucose being added ( $25 \mathrm{mg} \mathrm{g}^{-1}$ of litter dry weight)
90 min prior to a 90 min-incubation at $25{ }^{\circ} \mathrm{C}$. SIR rates were converted into microbial biomass using equations given by Beare et al. (1990).

Microbial respiration was expressed as $\mu \mathrm{g}$ of $\mathrm{C}$ produced as $\mathrm{CO}_{2}$ per gram of dry litter per hour. Metabolic Coefficient $\left(\mathrm{qCO}_{2}\right)$ was calculated as the ratio of basal respiration/microbial biomass according to Anderson and Domsch (1985).

\subsection{Extracellular enzyme activities (EEA)}

Laccase (LAC), cellulase (CEL), $\beta$-1,4-glucosidase ( $\beta G L U$ ), and acid phosphomonoesterases (PHA) activities were determined before introducing litters in the bags and after 2-, 5- and 13-month from a sub-sample of each litterbag. EEA were measured using a litter enzyme extract following a modified protocol from Criquet et al. (1999). Briefly, $10 \mathrm{~g}$ of litter was added to $200 \mathrm{ml} \mathrm{CaCl} 2,2 \mathrm{H} 2 \mathrm{O}(200 \mathrm{mM})$ and $0.1 \%$ Tween 80 , and then shaken for $1 \mathrm{~h}$ ( $500 \mathrm{rpm})$. The floating debris was removed, the extract was centrifuged (7000 $\mathrm{g}$ for $20 \mathrm{~min}$ ) and the supernatant was filtered (Whatman, GF/C, $2.7 \mu \mathrm{m}$ ). The filtrate was concentrated by dialysis tubes (12-14 KDa-porosity) using Poly-Ethylene Glycol (PEG). Concentrated extract was obtained by adding $15 \mathrm{~mL}$ of $10 \mathrm{mM}$ BisTris buffer ( $\mathrm{pH} \mathrm{6}$ ). The reaction mixtures for all the enzyme activities performed with the enzyme extract consisted of $300 \mu \mathrm{l}$ of enzyme extract with $700 \mu \mathrm{l}$ of the corresponding buffer at $30^{\circ} \mathrm{C}$, except for cellulase activity which was incubated at $50{ }^{\circ} \mathrm{C}$. Laccase activity was measured by monitoring the oxidation of syringaldazine to its quinone $\left(\varepsilon^{\mathrm{M}}=65000 \mathrm{M}^{-1} \mathrm{~cm}^{-1}\right)$ at $525 \mathrm{~nm}$ in acetate buffer $(100 \mathrm{mM}$, $\mathrm{pH}$ 4.5). CM-cellulase (EC 3.2.1.4) activity was assayed using Carboxy Methyl Cellulose (CMC) at $0.7 \%(\mathrm{w} / \mathrm{v})$ as substrate with sodium acetate buffer ( $50 \mathrm{mM}, \mathrm{pH} 6$ ). After a $4 \mathrm{~h}$-incubation, the glucose released was quantified according to Farnet et al. (2010). $\beta$-1,4-glucosidase activity was performed using $p$-nitrophenyl $\beta$-D-glucopyranoside $(0.2 \mathrm{mM})$ with sodium acetate buffer (100 mM, pH 5.6). Phosphomonoesterase was assayed using $p$-nitrophenyl phosphate monoester $(0.2 \mathrm{mM})$ in sodium acetate buffer (100 mM, pH 4.5) and $\mathrm{NaOH}$-glycine buffer (100 mM, pH 9.0) for acid and alkaline phosphomonoesterases respectively. $p$-nitrophenol was quantified at $412 \mathrm{~nm}$ after the addition of $\mathrm{NaOH}(0.5 \mathrm{M})$. All analytical experiments were performed in triplicate for each litterbag. One unit (U) of enzyme activity is defined as one $\mu$ mole of the reaction product formed per $h$ and per $g$ of litter dry weight $\left(\mathrm{U} \mathrm{gdw}^{-1}\right)$.

\subsection{Community-level physiological profiles (CLPP)}

Catabolic profiles of microbial communities were assessed using Biolog EcoPlate ${ }^{\mathrm{TM}}$ (Biolog, California, USA). Briefly, $2 \mathrm{~g}$ of dry litter was added to $100 \mathrm{~mL}$ of $0.1 \%$ sodium pyrophosphate sterile buffer in a $250 \mathrm{~mL}$ flask and shaken for $1 \mathrm{~h}(500 \mathrm{rpm})$. One extraction from litter of each litterbag was performed. The litter suspension was diluted and standardized at OD $595 \mathrm{~nm}=0.02$ with a sterile physiological solution ( $\mathrm{NaCl} 0.85 \%) .125 \mu \mathrm{L}$ of microbial suspension were used to inoculate each well. The plates were incubated at $25{ }^{\circ} \mathrm{C}$ for 5 days and microbial development was followed by reading the absorbance at $590 \mathrm{~nm}$. According to Garland (1997), absorbance value for each well was blanked against the control well and negative absorbance values were set to zero. The minimum OD for a positive well was fixed at 0.25 . The OD after $45 \mathrm{~h}$ has been chosen according to exponential phase of growth curves for all plates for further comparison.

Overall rate of substrate utilization by microorganisms was measured by calculating the Average Well Color Development (AWCD) for each plate $(\mathrm{n}=3)$ at $45 \mathrm{~h}$. Functional diversity assessed by Shannon's diversity index $\left(\mathrm{H}^{\prime}\right)$ was calculated using the equation: $\mathrm{H}^{\prime}=-\sum \mathrm{pi}$ log pi where pi is defined as OD of each well/sum of OD of all wells. Species evenness was calculated via Pielou's Index, $\mathrm{J}^{\prime}=\mathrm{H}^{\prime} / \mathrm{H}^{\prime}$ max and species richness, $\mathrm{S}$, was calculated as the number of substrates used. 
2.6. Chemical characterization of litter by $\mathrm{C} / \mathrm{N}$ and the cross-polarization magic angle spinning ${ }^{13} \mathrm{C}$ nuclear magnetic resonance $\left(\mathrm{CP} / \mathrm{MAS}{ }^{13} \mathrm{C} N \mathrm{NR}\right)$

Total organic carbon (TOC) and total nitrogen were measured as follows: dried sub-samples of initial litter and of each litterbag's litter were powdered in a ceramic mortar and analyzed by combustion in an Elemental Analyzer, FlashEA 1112, Thermofisher.

$\mathrm{CP} / \mathrm{MAS}{ }^{13} \mathrm{C}$ NMR spectra were obtained on a Bruker DSX $400 \mathrm{MHz}$ spectrophotometer operating at $100.7 \mathrm{MHz}$. Samples (600 mg) were spun at $10 \mathrm{KHz}$ at the magic angle. Contact times of $2 \mathrm{~ms}$ were applied with a pulse width of $2.8 \mu \mathrm{s}$ and a recycle delay of $3 \mathrm{~s}$. Chemical shift values were referenced to glycine signal (carbonyl $C$ at $176.03 \mathrm{ppm}$ ). Seven common chemical shift regions were defined according to Mathers et al. (2007): alkyl C (0-45 ppm), methoxyl C (45-60 ppm), O-alkyl C (60-92 ppm), di-O-alkyl C (92-112 ppm), aromatic C (112-142 ppm), phenolic C (142-160 ppm) and carboxyl C (160-185 ppm). Aromaticity Ratio (AR) was calculated by dividing the sum of aromatic $C$ and phenolic $C$ by the sum of all regions except methoxyl C. Dmfit 2003 software was used to determine the intensity of each chemical-shift-region (Massiot et al., 2002).

\subsection{Statistical analysis}

A three-way ANOVA was performed taking into account litterbag location (C10 and C300), litter origin area (C10, C300) and time (June, September, May) as factors and using microbial respiration, enzyme activities, AWCD and $\mathrm{H}^{\prime}$ calculated from Biolog as dependent variables. Data were transformed as necessary to respect the normality and homogeneity of variance in parametric ANOVA. Because the time factor had a significant effect on almost all variables, the litterbags for each sampling time were further compared individually by a non-parametric comparison of Kruskal-Wallis. Test $t$ was performed for comparison between $\mathrm{C} 10$ and $\mathrm{C} 300$ at $\mathrm{t} 0$.

All the measured microbial variables were subjected to Principal Component Analysis (PCA). PCA was also performed on Biolog data considering OD after $45 \mathrm{~h}$ incubation as variables (31 substrates). Statistica Vs 6 (StatSoft, Maison-Alfort, France) was used for statistical analysis and $\mathrm{p}$-value $<0.05$ was considered as significant.

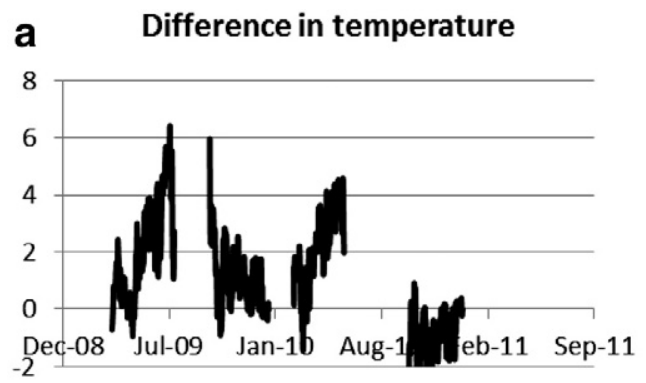

C Difference in conductivity

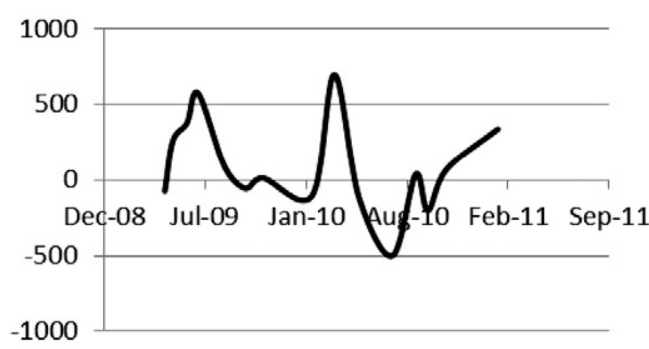

\section{Results}

3.1. Environmental parameters at a local scale over a one-year monitoring period

Temperature, humidity, conductivity and chloride concentration were monitored in litters collected in the two areas at 10 or $300 \mathrm{~m}$ from the coastal line throughout the experimental time and at least each two months (Fig. 1). Minimum and maximum of the different parameters are shown in Table 1. Similar seasonal variations in these parameters were observed for both areas. However, over the monitoring period, temperature was higher in the area close to the coastal line ( $1.8^{\circ} \mathrm{C}$ year average). Mean of daily temperatures varies between 2 and $28{ }^{\circ} \mathrm{C}$ and the difference in temperature reached $7{ }^{\circ} \mathrm{C}$ during summer with the higher value in the area close to the coastal line (Fig. 1a). Consequently, litter humidity was slightly higher in litter from the area at $300 \mathrm{~m}$ from the coastal line (Fig. 1b). Over the monitoring period, maximum and minimum humidity was $63 \%$ and $10 \%$, respectively. In summer, conductivity differences between the two areas were intensified, i.e. when humidity was low in both areas, conductivity was higher in the area close to the coastal line. Differences in conductivity between the two areas reached a maximum value of $300 \mathrm{ppm}$ and these values of conductivity varied always the same way as those of chloride ion concentration (Fig. 1c and d). pH variations were similar for both areas with acidic $\mathrm{pH}$, slightly lower in the area close to the coastal line (annual mean $\mathrm{pH}$ were $6.6 \pm 0.4$ vs $6.0 \pm 0.4$, respectively).

\subsection{Chemical evolution of litters}

Different chemical markers, i.e. solid-state NMR of ${ }^{13} \mathrm{C}$ and $\mathrm{C} / \mathrm{N}$, were used to characterize litters. Fig. 2a and b respectively shows the variations in these markers both in litterbag controls (C10/C10 or C300/C300) and in the litterbags exchanged between the two areas (litter C10 in area C300, C10/C300, or litter C300 in area C10, C300/C10) over 13 months. Compared to t0, $\mathrm{C} / \mathrm{N}$ was lower whatever the litterbag considered. Over this monitoring period, $\mathrm{C} / \mathrm{N}$ was always higher in $\mathrm{C} 300 / \mathrm{C} 300$ than in $\mathrm{C} 10 / \mathrm{C} 10$ and it is important to note that after 13 months, $\mathrm{C} / \mathrm{N}$ varied depending on the origin of litter: ratios were the same in $\mathrm{C} 10 / \mathrm{C} 10$ and

\section{b Difference in humidity}

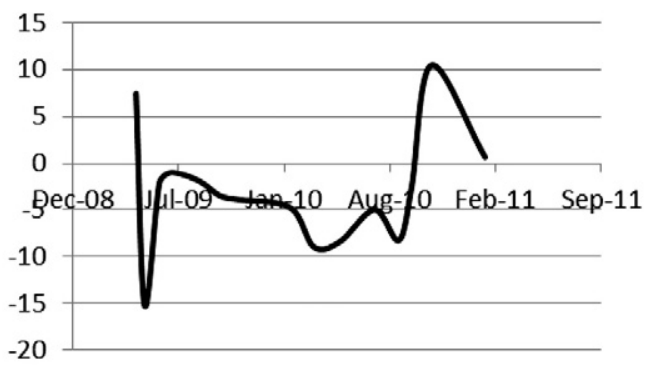

\section{d Difference in $\mathrm{Cl}^{-}$concentration}

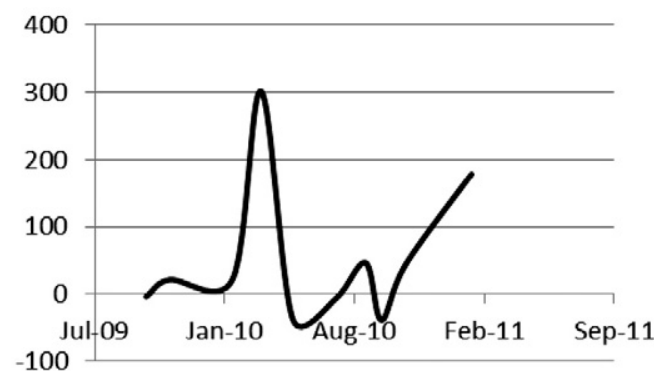

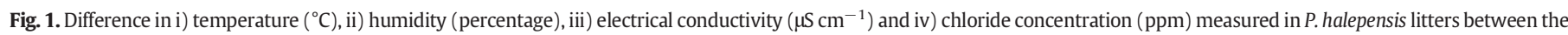
areas located close $(10 \mathrm{~m})$ and far $(300 \mathrm{~m})$ from the coast, respectively $(\mathrm{n}=3)$. 
Table 1

Minimum and maximum of the environmental parameters monitored in litters over a one-year period in C10 and C300 areas (respectively at $10 \mathrm{~m}$ and $300 \mathrm{~m}$ from the sea shore).

\begin{tabular}{llllll}
\hline & $\mathrm{C} 10$ & & & \multicolumn{2}{c}{ C300 } \\
\cline { 2 - 3 } & Min & Max & & Min & Max \\
\hline Temperature $\left({ }^{\circ} \mathrm{C}\right)$ & 5.7 & 28 & & 2.5 & 25 \\
Humidity $(\%)$ & 11 & 63 & & 12 & 57 \\
$\mathrm{EC}\left(\mu \mathrm{S} \mathrm{cm}{ }^{-1}\right)$ & $255( \pm 17)$ & $1454( \pm 49)$ & & $277( \pm 10)$ & $880( \pm 14)$ \\
$\mathrm{Cl}^{-}(\mathrm{ppm})$ & $56( \pm 14)$ & $397( \pm 7)$ & & $33( \pm 0)$ & $298( \pm 16)$ \\
\hline
\end{tabular}

C10/C300 on one side and C300/C10 and C300/C300 on the other side. AR was calculated from NMR data to follow both humification process and thus the quality of organic matter. We found that, while AR ratio was the same whatever the litter bag considered at $\mathrm{t} 0$, it was higher in $\mathrm{C} 10 / \mathrm{C} 10$ than in $\mathrm{C} 300 / \mathrm{C} 300$ for the two last sampling times. An increase in AR was observed in C10/C10 over time, which was not the case for the other litters. For instance, after 13 months, the AR of C10/C10 was higher than that of the exchanged litter C10 in C300 showing a decrease in aromatic compound proportion when litter C10 was exchanged. Considering both chemical indicators, after 13 months, organic matter was composed of a higher quantity of aromatic compounds in area C10 and the amount of carbon compared to nitrogen was lower.
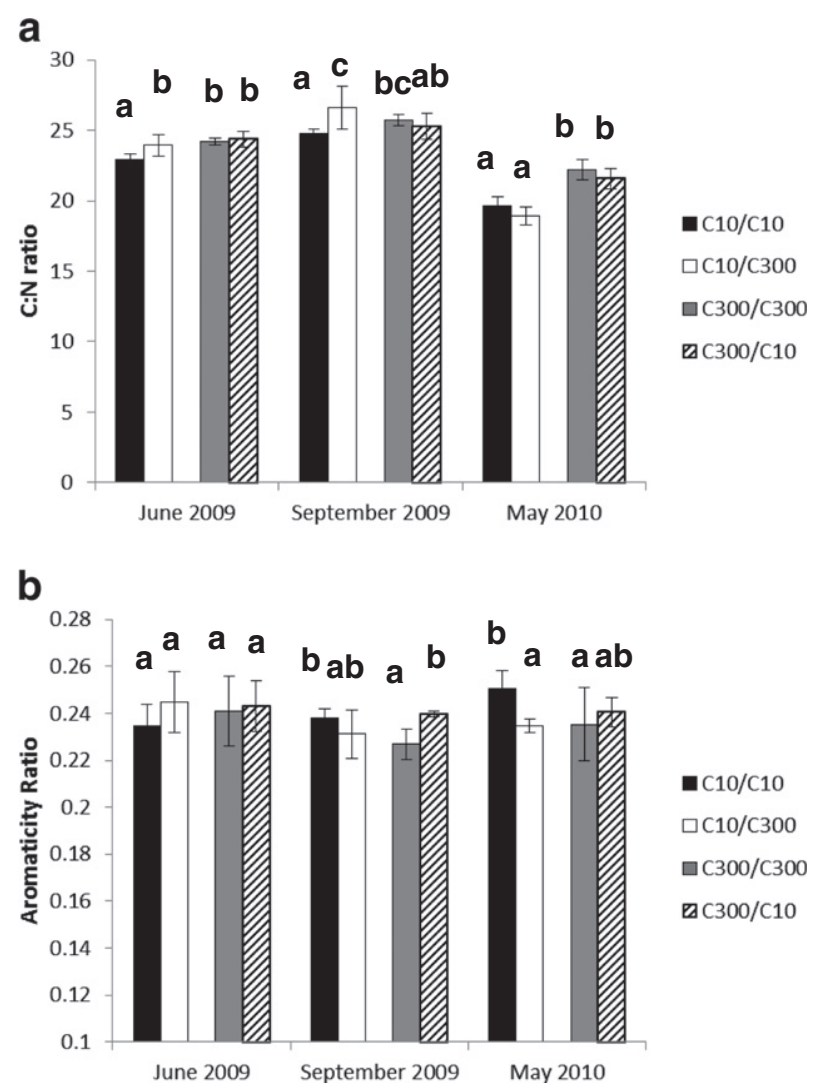

Fig. 2. C:N ratio (a) and Aromaticity ratio (b) calculated from litterbags after 2 (June), 5 (September), and 13 (May) months in litterbags. Litterbags C10/C10 (black) and C10 C300 (white) are litters from area C10 placed in area C10 or C300, respectively. Litterbags C300/C300 (gray) and C300/C10 (dash) are litters from area C300 placed in area C300 or $\mathrm{C} 10$, respectively. Different letters show the means of each sampling time which are significantly different $(\mathrm{p}<0.05)$ following Kruskal-Wallis non parametric comparison of means. Values at t0 for $\mathrm{C}: \mathrm{N}$ ratio were $27( \pm 1)$ and $33( \pm 4)$ for $\mathrm{C} 10$ and $\mathrm{C} 300$, and for Aromaticity ratio were $0.30( \pm 0.02)$ and $0.32( \pm 0.01)$ for $\mathrm{C} 10$ and $\mathrm{C} 300$, respectively.
3.3. Variations in microbial activities: extracellular enzymes, $B R, q \mathrm{CO}_{2}$ and $A W C D$

We first analyzed the microbial characteristics of the composite samples of litter (before litter was placed in litterbags) from area C10 and C300 at t0 (April 2009). Lignocellulolytic activities (laccase and cellulase) were higher in litter from area C300 than from area C10, while no differences were found for both $\beta$-glucosidase and phosphatase activities. All enzyme activities were indeed higher in litter C300 (litterbags C300/C300) than in litter C10 (litterbags C10/C10) over 13 months except for laccases. It is noteworthy that placing litter C300 in area C10 (C300/C10) also affected most of the enzyme activities tested over the experiment (C300/C10 < C300/C300), (Fig. 3). On the other hand, when comparing $\mathrm{C} 10 / \mathrm{C} 10$ and C10/C300, few effects were found for all the enzyme activities. Overall, independent of seasonal variations, enzyme activities in litterbags follow this trend: C300/C300 $>\mathrm{C} 300 / \mathrm{C} 10=\mathrm{C} 10 / \mathrm{C} 300>\mathrm{C} 10 / \mathrm{C} 10$. This trend was less marked for sampling date September 2009, which may be directly linked to summer drought effect influencing microbial responses.

BR were compared at t0 and we found that litter C10 had a lower level of BR than litter C300. Fig. 4a shows BR levels in P. halepensis litter in litterbags over 13-months in areas C10 and C300. Respiration was measured at standard humidity i.e. at the maximum humidity detected in both areas over one year (60\%, Fig. 1b). BR of litters without standardizing humidity revealed great differences because of seasonal humidity variations especially in June-09 (data not shown). BR values after 2 months (June 09) are similar whatever the litterbags considered (C10/C10, C10/C300, C300/C10 and C300/C300), as shown in Fig. 4a. After 13 months, BR in area C300 is higher than in area C10 (C300/ C300 litterbags vs C10/C10 litterbags) and furthermore, BR values followed this trend $\mathrm{C} 10 / \mathrm{C} 10=\mathrm{C} 300 / \mathrm{C} 10<\mathrm{C} 300 / \mathrm{C} 300=\mathrm{C} 10 / \mathrm{C} 300$ showing the importance of the area. $\mathrm{qCO}_{2}$ was calculated as the ratio of BR to biomass estimated via SIR (Fig. 4b). At t0, a difference was observed depending on litter origin while after 13 months, the effect of area was predominant showing that catabolic potential of microbial communities was higher in area $\mathrm{C} 300$ than in area $\mathrm{C} 10$ whatever the litter origin $(\mathrm{C} 10 / \mathrm{C} 10=\mathrm{C} 300 / \mathrm{C} 10<\mathrm{C} 300 / \mathrm{C} 300=\mathrm{C} 10 / \mathrm{C} 300)$.

AWCD, calculated from Biolog data, is considered as an indicator of global microbial activity. Here, it varied with litter origin (Fig. 4c) after 2 months (AWCD C10/C10 similar to C10/C300 and AWCD C300/ C300 to C300/C10) while, after 13 months, it varied with the area $(\mathrm{C} 10 / \mathrm{C} 10=\mathrm{C} 300 / \mathrm{C} 10<\mathrm{C} 300 / \mathrm{C} 300=\mathrm{C} 10 / \mathrm{C} 300)$.

Thus, for $\mathrm{BR}, \mathrm{qCO}_{2}$ and $\mathrm{AWCD}$, a similar tendency is observed at the end of the experiment, indicating the strong influence of the area on these microbial indicators. It is noteworthy that the same variation in BR and AWCD between areas C10 and C300 was found at t0 (April 2009) and after 13 months (May 2010) and thus for the same season (spring).

\subsection{Variations in microbial diversity assessed via CLPP}

PCA was performed from all the optical densities obtained from Biolog microplates after $45 \mathrm{~h}$ (exponential phase). Fig. 5 shows that projections were gathered depending on sampling time. Furthermore, PCA also revealed the influence of different factors (litter origin or area) over the experiment: after 2 months, projections were gathered depending on litter (C10/C10 and C10/C300 vs C300/C300 and C300/C10) while after 13 months the effect of the area was observed (C10/C10 and C10/C300 vs $\mathrm{C} 300 / \mathrm{C} 300$ and $\mathrm{C} 10 / \mathrm{C} 300)$. Moreover, after 5 months, the projections clearly indicate that placing litter C300 in area C10 strongly affected catabolic profiles compared to the three other types of litterbags.

\subsection{Correlation between microbial indicators and environmental factors}

ANOVA was performed in order to assess the most determinant environmental factor which influenced microbial activities (Table 2). 


\section{a) Laccase}

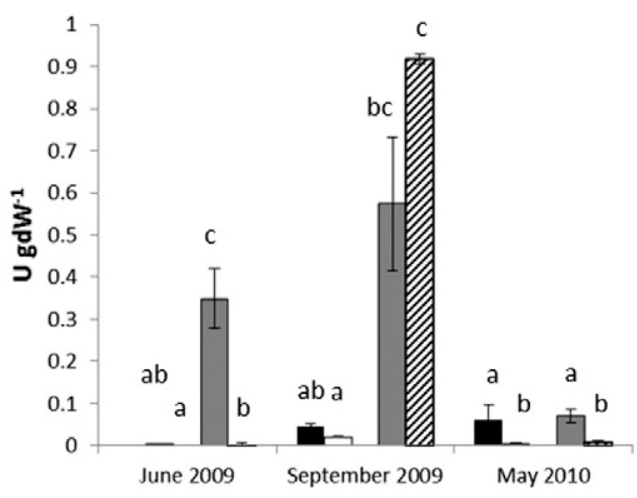

\section{c) $\beta$-glucosidase}

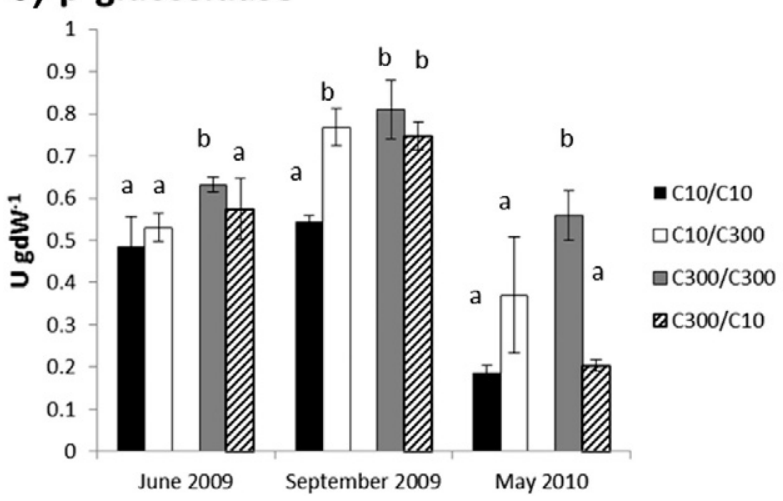

\section{b) Cellulase}

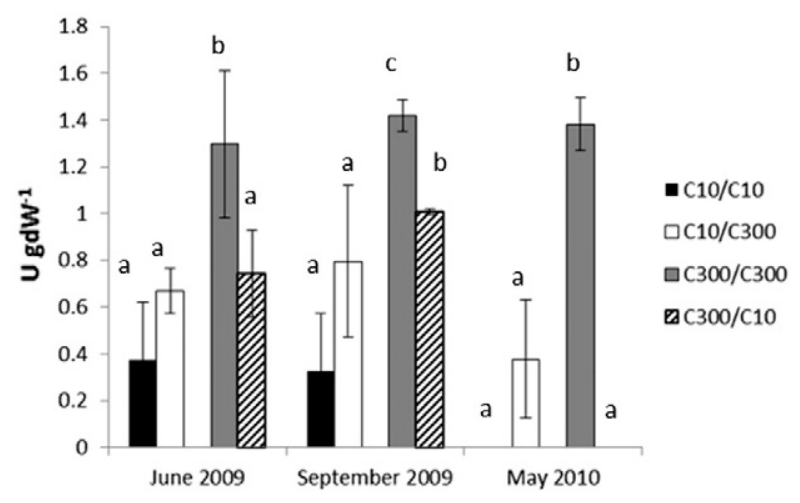

\section{d) Phosphatase}

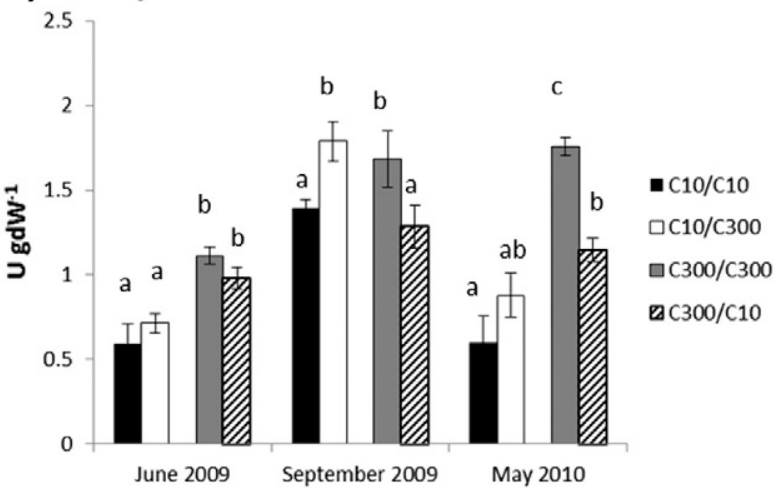

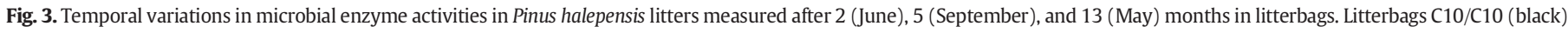

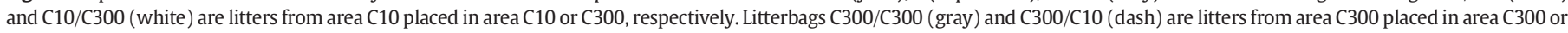

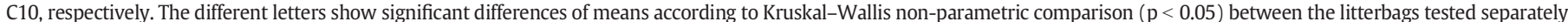

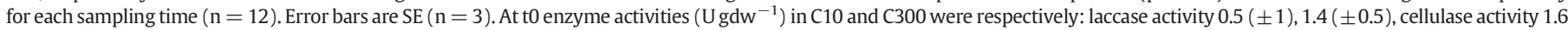
$( \pm 0.3), 3.2( \pm 0.5)$, phosphatase activity $0.8( \pm 0.1), 0.7( \pm 0.1)$, and $\beta$-glucosidase activity $0.6( \pm 0.1), 0.6( \pm 0.0)$.

Factor time linked to seasonal climate variations, significantly affect all microbial indicators except cellulase activities. Litter origin is also an important factor which influenced all microbial indicators except BR. The area has an effect on AWCD and the enzyme activities. Of all the assayed enzymes in this study, only laccase was significantly correlated to all three tested factors considered independently or together.

The PCA obtained from microbiological markers $\left(\mathrm{H}^{\prime}, \mathrm{J}^{\prime}, \mathrm{S}\right.$ and AWCD from Biolog data, BR, SIR and the four extracellular enzyme activities) according to F1 and F2 (69\% of variance) is shown in Fig. 6 and points out a seasonal effect: projections of the different litter bags are gathered according to sampling time. For each sampling time C10/C10 and C300/ C300 projections were clearly separated from each other. After 2 months, placing litter C300 in area C10 strongly affected all the biological markers under consideration (C10/C10, C10/C300 and C300/C10 vs C300/C300) while after 5 months, the effect of litter was observed (C10/C10 and C10/C300 vs C300/C300 and C300/C10) and after 13 months, this was the effect of the area.

\section{Discussion}

Climatic variations and litter chemical quality largely determine the structure of microbial communities and thus their functioning, mainly the potential of organic matter decomposition (Coûteaux et al., 1995; Kourtev et al., 2002; Ayres et al., 2009). However, at a local scale, microclimatic variations can affect microbial communities and consequently their functioning (Sommerkorn, 2008; Nannipieri et al., 2003). Here, we explored whether microclimatic conditions, which can be enhanced in a coastal environment (i.e. differences in salinity exposure, humidity, temperature, etc.), caused a variation in microbial activities. Thus, first, it was important to demonstrate how micro-environmental characteristics actually varied at a local scale i.e. between the two selected areas. We indeed observed that the areas studied, which are subjected to the same annual climate conditions, were highly differentiated with respect to certain parameters. For instance, temperature variation is strongly different between both areas, with a higher temperature $\left(7^{\circ} \mathrm{C}\right.$ higher) in the area close to the coastal line, which can be partly explained by both topography (sites chosen were at around 10- and 350-m high) and exposition. Moreover, during summer drought, conductivity linked to salinity exposure via sea sprays, which is a major environmental structuring factor in coastal ecosystems, is more intense in litters situated at the coast line than in those farther inland probably because of differences in wind conditions. Thus, these results show that osmotic stresses (mainly a higher conductivity and desiccation) are stronger in the area close to the coastal line and also vary over time.

Of the various microbial indicators, enzyme activities are particularly important since they provide information on the metabolic state of microbial communities and their potential to transform organic matter (Caldwell, 2005; Sinsabaugh et al., 2002). The activity of various degrading enzymes is known to decrease in saline environments via a direct effect since salts particularly disturb the tridimensional structure of proteins and/or to inhibit the catalyzed reaction (Farnet et al., 2008; Zahran, 1997). Different studies on osmotic stress as a determinant factor influencing microbial activities have also found that microbial biomass decreases when salinity increases as an effect of osmotic stress on the cells (Wichern et al., 2006; Muhammad et al., 2008; Egamberdieva et al., 2010). Rietz and Haynes (2003) who studied both enzyme activities and microbial biomass, proposed that an increase in salinity results in metabolically less efficient microbial communities. 


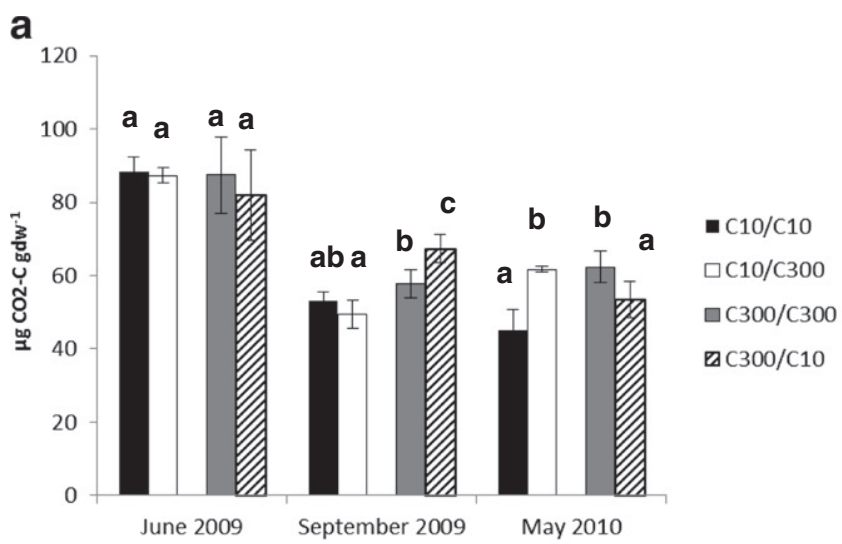

b
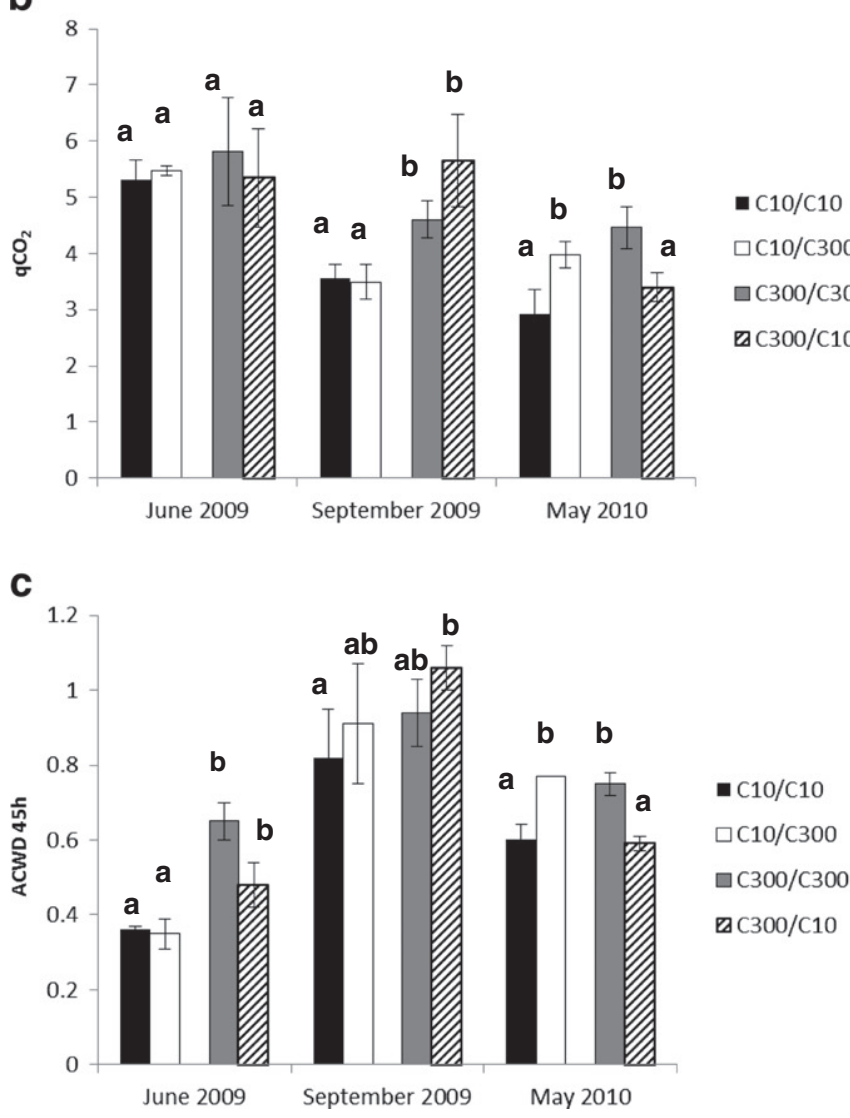

Fig. 4. Basal Respiration (a), Metabolic quotient $\mathrm{qCO}_{2}$ (b) and $\mathrm{AWCD}$ calculated from Biolog after $45 \mathrm{~h}$ after 2 (June), 5 (September), and 13 (May) months. Litterbags C10/C10 (black) and C10/C300 (white) are litters from area C10 placed in area C10 or C300, respectively. Litterbags C300/C300 (gray) and C300/C10 (dash) are litters from area C300 placed in area C300 or C10, respectively. The different letters show significant differences of means according to Kruskal-Wallis non parametric comparison $(\mathrm{p}<0.05)$ between the litterbags tested separately for each sampling time. Error bars are $\mathrm{SE}(\mathrm{n}=3)$. At t0 BR, $\mathrm{qCO}_{2}$ and AWCD were respectively in C10 and C300: $43( \pm 2), 49( \pm 2), 2.9$ $( \pm 0.0), 3.5( \pm 0.0), 0.6( \pm 0.0)$, and $0.8( \pm 0.0)$.

Here our results highlight that microbial activities involved in $P$. halepensis litter decomposition are affected by osmotic stresses since i) enzyme activities were lower in area C10 than in area C300 and ii) most enzyme activities produced in litter C300 decreased when the litter was placed in the C10 area, near the coast. Laccases are the only enzymes for which variations are explained by all three tested factors (considered alone or together, Table 2). Our previous study (Qasemian et al., 2012), has shown that laccase production under stressful condition (pollutant addition) was highly dependent on litter

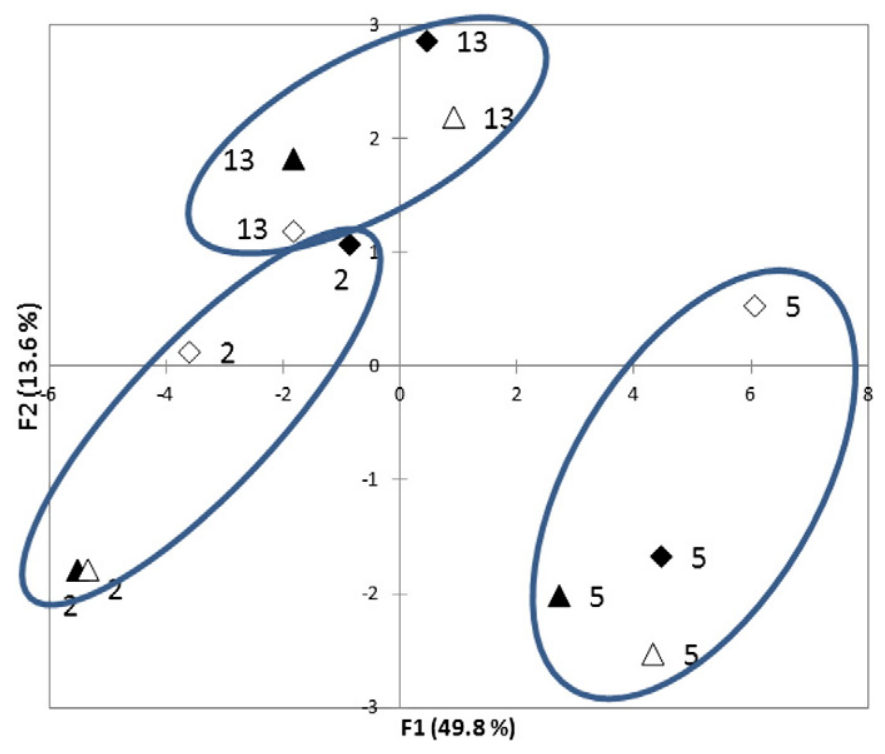

Fig. 5. PCA from Eco plate substrate utilization profile of litterbags after 2, 5 and 13 months. Triangle corresponds to litter from C10 area placed in C10 area (black) and placed in C300 area (white). Diamond-shape corresponds to litter from C300 area placed in C300 area (black) and placed in C10 area (white). Each point represents the barycenter of nine litterbags $(n=9)$.

origin (coastal or inland area). These enzymes can be considered as markers of fungal activity which, here, vary depending on time, area and litter. For instance, Toberman et al. (2008) showed that phenoloxidase activities strongly decreased during summer drought, which can be linked to a decrease in fungal diversity. Here, we observed a greater expression of lignocellulolytic enzymes in area C300, which may be partly explained by a higher level of humidity in area C300 (Fig. 1). Cellulase and $\beta$-glucosidase variations had indeed nearly the same pattern as laccase: lignocellulolytic activities are known to be extensively produced by fungal communities and thus laccase and cellulase activities are supposed to follow similar temporal and spatial variations (Baldrian, 2006; Baldrian and Valaskova, 2008). In litters from schlerophyllous plants such as $P$. halepensis, fungal communities play an important role in organic matter decomposition and their biodiversity strongly varies with litter type and habitat (Sinsabaugh, et al., 2002). Sardinha et al. (2003) have suggested a shift in microbial communities towards bacterial populations under saline conditions using the ratio ergosterol to microbial biomass. Chowdhury et al. (2011) have also found that fungal populations were more sensitive to osmotic stress than bacteria.

Like other authors, we found microbial respiration to be highly dependent on humidity (Schimel et al., 1999; Zhu et al., 2008; Emel et al., 2008). Thus, in order to avoid variations due to different percentages of humidity in the samples, we compared microbial respiration at the highest in situ humidity measurement. The highest BR values were obtained, whatever the litterbags considered, in June 09, which corresponds to the summer drought period (Fig. 1b). Iovieno and Baath (2008) in a study involving soil rewetting, have demonstrated that an immediate increase in microbial respiration is usually observed when rewetting completely dried samples. Thus, the same level of BR obtained in June 09 (2 months) for all litterbags may not be totally explained by in situ variations: this can be explained by cell lysis due to osmotic shock, which enhances microbial respiration of surviving microorganisms via nutrient release (Bottner, 1985; Turner et al., 2003). Just as in previous studies comparing microbial metabolisms in native and non-native environments, we also observed here that microbial respiration was influenced by new environmental conditions i.e. after litter transfers (Kourtev et al., 2002). After 13 months, basal respiration indeed depended on where the litter was placed, and decreases in 
Table 2

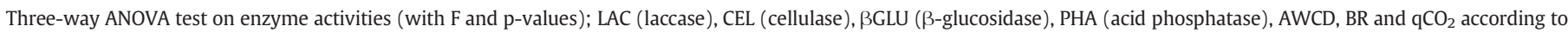
different factors: Area (C10 and C300), Litter (from C10 and C300) and Time (June, September and May).

\begin{tabular}{|c|c|c|c|c|c|c|c|c|c|c|c|c|c|c|}
\hline \multirow[t]{2}{*}{ Variables } & \multicolumn{2}{|l|}{$\mathrm{LAC}^{\mathrm{a}}$} & \multicolumn{2}{|l|}{$\mathrm{CEL}^{\mathrm{a}}$} & \multicolumn{2}{|c|}{$\beta G L U^{a}$} & \multicolumn{2}{|l|}{$\mathrm{PHA}^{\mathrm{a}}$} & \multicolumn{2}{|c|}{ AWCD } & \multicolumn{2}{|l|}{$\mathrm{BR}^{\mathrm{a}}$} & \multicolumn{2}{|c|}{$\mathrm{qCO}_{2}$} \\
\hline & $F$ & $\mathrm{p}$ & $F$ & $\mathrm{p}$ & $F$ & $\mathrm{p}$ & $F$ & $\mathrm{p}$ & $F$ & $\mathrm{p}$ & $F$ & $\mathrm{p}$ & $F$ & $\mathrm{p}$ \\
\hline Area & 13.2 & $<0.01$ & 16.1 & $<0.001$ & 61.8 & $<0.0001$ & 21.1 & $<0.001$ & 5.1 & $<0.05$ & 0.0 & ns & 0.2 & ns \\
\hline Time & 343.7 & $<0.0001$ & 2.4 & ns & 48.2 & $<0.0001$ & 64.6 & $<0.0001$ & 68.4 & $<0.0001$ & 42.7 & $<0.0001$ & 9.1 & $<0.01$ \\
\hline Litter & 507.5 & $<0.0001$ & 12.1 & $<0.01$ & 10.0 & $<0.01$ & 27.5 & $<0.0001$ & 11.3 & $<0.01$ & 1.4 & ns & 4.9 & $<0.05$ \\
\hline Area $\times$ time & 37.6 & $<0.0001$ & 3.3 & ns & 20.9 & $<0.0001$ & 1.0 & ns & 2.5 & ns & 1.6 & ns & 1.7 & ns \\
\hline Area $\times$ litter & 132.8 & $<0.0001$ & 2.1 & ns & 1.8 & ns & 0.1 & ns & 0.0 & ns & 0.0 & ns & 0.3 & ns \\
\hline Time $\times$ litter & 14.2 & $<0.001$ & 0.7 & ns & 0.0 & ns & 15.6 & $<0.001$ & 3.9 & $<0.05$ & 3.5 & $<0.5$ & 2.8 & ns \\
\hline Area $\times$ time $\times$ litter & 113 & $<0.0001$ & 1 & ns & 1.9 & ns & 0.2 & ns & 2.9 & ns & 0.8 & ns & 1.1 & ns \\
\hline
\end{tabular}

${ }^{\mathrm{a}}$ Log transformed, $\mathrm{ns}=$ non-significant ANOVA test, $\mathrm{p}=0.05$.

area $\mathrm{C} 10$ (C10/C10 and $\mathrm{C} 300 / \mathrm{C} 10)$ sustain previous studies where the authors found that osmotic stress had an impact on microbial respiration (Wichern et al., 2006; Muhammad et al., 2008). However, it is
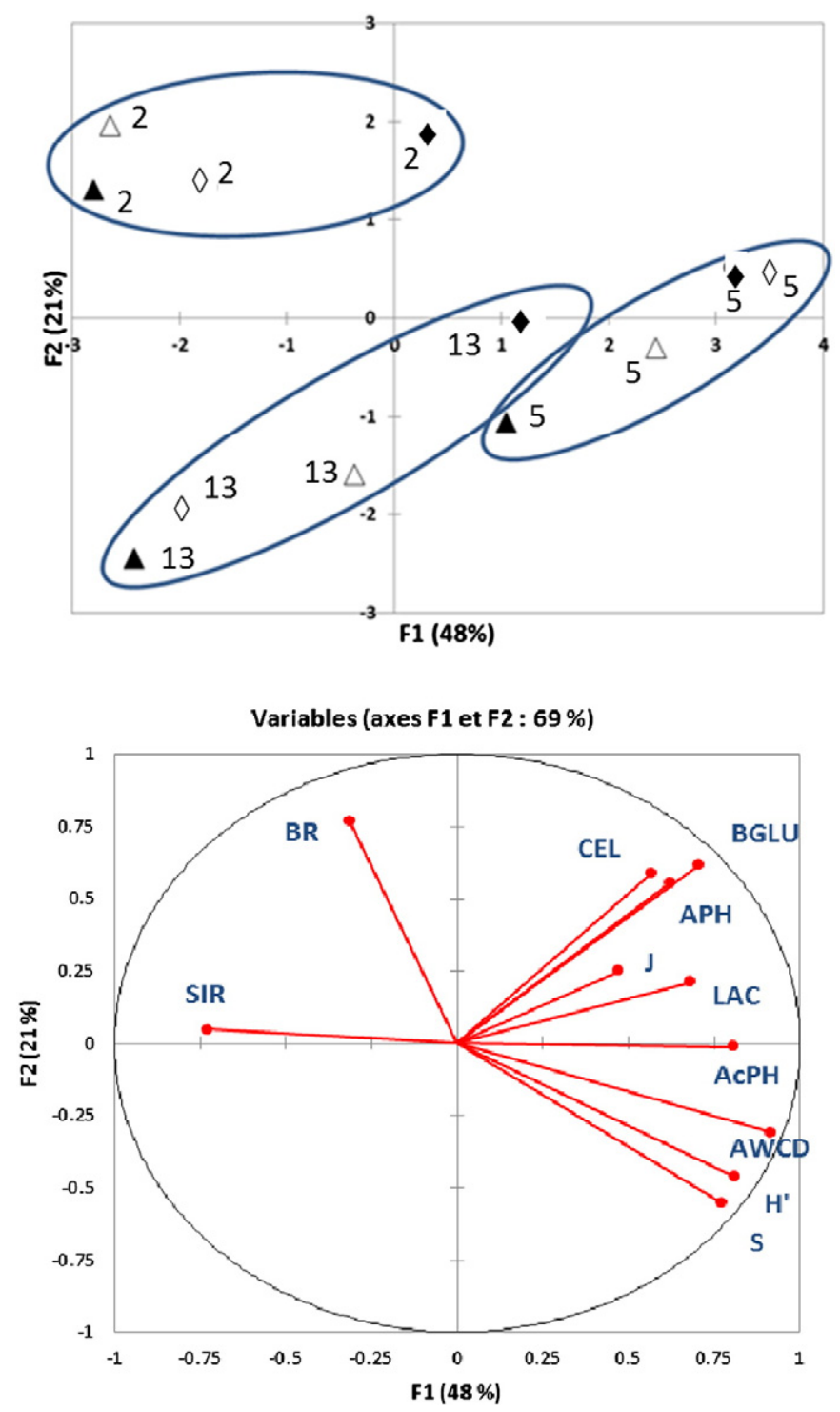

Fig. 6. PCA on microbial markers measured in litterbags after 2,5 and 13 months. Triangle corresponds to litter from C10 area placed in C10 area (black) and placed in C300 area (white). Diamond-shape corresponds to litter from C300 area placed in C300 area (black) and placed in C10 area (white). Each point represents the barycenter of nine litterbags $(n=9)$. SIR: substrate-induced respiration, BR: basal respiration, CEL: Cellulase, BGLU: $\beta$-galactosidases, LAC: laccases, APH: alkaline phosphatases, AcPH: acid phosphatases, AWCD: Average Well Color Development, $\mathrm{H}^{\prime}$ : Shannon-Weaver Index, J': Pielou's Index, S: Richness. noteworthy that, microbial biomass (estimated by SIR) is not affected by the area in our study. Previous studies have described different fluctuations in microbial biomass with increasing osmotic stress as shown by Rajaniemi and Allison (2009) using phospholipid fatty acid profile (PLFA). Another key factor which may have indeed influenced the microbial biomass of the microbial communities is the chemical quality of the litter inside the litterbags after 13 months. Aromaticity ratio was indeed higher in area C10 than in area C300 and phenol compounds are known to have a strong effect on the activities of microbial communities. Setia et al. (2011) have also highlighted that humic substances greatly influenced the magnitude of the osmotic stress effect on respiration.

On the other hand, the metabolic quotient after 13 months was higher in C300 than in C10: the functional potential of microbial communities in litter depended also on local environmental conditions. Thus, it appears that, while local micro-variations in temperature, humidity and salinity do not affect the quantity of microorganisms, they influence their metabolic potential, characterized by $\mathrm{qCO}_{2}$. This finding reveals that microbial communities from C300 area are probably weakened under these conditions since $\mathrm{qCO}_{2}$ increase usually indicates the presence of microorganisms using labile carbon compounds i.e. copiotrophs (Koch, 2001). This functional category of fast-growing microorganisms is known to have few skills to adapt to drastic environmental conditions. Thus an adaptation of microbial communities from C10 area to matric and osmotic stress may have occurred compared to that from C300 area, a finding in accordance with previous studies, which demonstrated that microbial communities subjected to natural drying/rewetting events rapidly got adapted to such kind of stresses (Fierer et al., 2003).

Certain authors claim out that there is no relationship between in situ salinity and salt-tolerant microorganism abundances, which suggests that soil salinity is not always a decisive factor for the structure of microbial communities (Rousk et al., 2011). Here we found that functional diversity of autochthonous microorganisms was influenced by the area and thus by microlocal environmental conditions, including salinity exposure. The effect of osmotic stresses on the structure of microbial communities has been previously assessed via various techniques such as PLFA. For instance, Rajaniemi and Allison (2009) have found that microbial community composition was modified by abiotic stresses and more specifically by salinity.

Though factors controlling microbial activities are well documented, determining other parameters shaping these activities at a micro-scale is also of huge importance especially in Mediterranean coastal areas, subjected to various natural and anthropic pressures. Our results confirm that the seasonal alternation of humid and dry periods is a major factor influencing litter microbial activities in Mediterranean area. However, our findings here also suggest that variations in microbial activities and functional diversity are influenced by microlocal conditions. Pollutant exposure via sea-spray can also be a key factor structuring microbial functioning in coastal environments. The role of all these environmental factors in the microbial community structure (fungal to bacterial community ratio or composition in salt-tolerant populations) should also be further investigated. 


\section{Conflict of interest}

There is no conflict of interest of any kind concerning this work.

\section{Acknowledgments}

This work is financially supported by a PhD grant of the French Environment and Energy Management Agency (ADEME) and the Provence Alpes Côtes d'Azur Region (France) to L. Qasemian. We are very grateful to Mrs Marjorie Sweetko for her assistance in English language and to Mr. I.M. Guardado Da Silva for his very helpful technical advices for field monitoring.

\section{References}

Anderson TH, Domsch KH. Determination of eco-physiological maintenance requirements of soil microorganisms in a dormant state. Soil Biol Biochem 1985;1(2):81-9.

Asia L, Mazouz S, Guiliano M, Doumenq P, Mille G. Occurrence and distribution of hydrocarbons in surface sediments from Marseille Bay (France). Mar Pollut Bull 2009; 58(1):443-51.

Ayres E, Steltzer H, Simmons BL, Simpson RT, Steinweg JM, Wallenstein MD, et al. Homefield advantage accelerates leaf litter decomposition in forests. Soil Biol Biochem 2009;41(3):606-10.

Ayuso SV, Guerrero MC, Montes C, López-Archilla AI. Regulation and spatiotemporal patterns of extracellular enzyme activities in a coastal, sandy aquifer system (Doñana, SW Spain). Microb Ecol 2011;62(1):162-76.

Baldrian P. Fungal laccases occurence and properties. FEMS Microbiol Rev 2006;30(2): $215-42$.

Baldrian P, Valaskova V. Degradation of cellulose by basidiomycetous fungi. FEMS Microbiol Rev 2008;32(3):501-21.

Beare MH, Neely CL, Coleman DC, Hargrove WL. A substrate-induced respiration (SIR) method for measurement of fungal and bacterial biomass on plant residues. Soil Biol Biochem 1990;22(2):585-94.

Bottner P. Response of microbial biomass to alternate moist and dry conditions in a soil incubated with C-14-labeled and N-15-labelledplant-material. Soil Biol Biochem 1985;17(3):329-37.

Caldwell BA. Enzyme activities as a component of soil biodiversity: a review. Pedobiologia 2005;49(6):637-44.

Chowdhury N, Marschner P, Burns R. Response of microbial activity and community structure to decreasing soil osmotic and matric potential. Plant and Soil 2011; 344(1-2):241-54.

Coûteaux MM, Bottner P, Berg B. Litter decomposition, climate and litter quality. Tree 1995;10(2):63-6.

Criquet S, Tagger S, Vogt G, Iacazio G, Le petit J. Laccase activity of forest litter. Soil Biol Biochem 1999;31(9):1239-44.

Egamberdieva D, Renella G, Wirth S, Islam R. Secondary salinity effects on soil microbial biomass. Biol Fertil Soils 2010;46(5):445-9.

Emel Z, Aka SH, Cengiz D. Carbon mineralization of Acacia cyanophylla soils under the different temperature and humidity conditions. Ekolojia 2008;18(1):1-6.

Farnet AM, Gil G, Ferré E. Effects of pollutants on laccase activities of Marasmius quercophilus, a white-rot fungus isolated from a Mediterranean schlerophyllous litter. Chemosphere 2008;70(3):895-900.

Farnet AM, Qasemian L, Guiral D, Ferré E. A modified method based on arsenomolybdate complex to quantify cellulase activities: application to litters. Pedobiologia 2010; 53(2):159-60.

Fierer N, Schimel JP, Holden PA. Influence of drying rewetting frequency on soil bacterial community structure. Microb Ecol 2003;45(5):63-71.

Fioretto A, Papa S, Pellegrino A, Fuggi A. Decomposition dynamics of Myrtus communis and Quercus ilex leaf litter: mass loss, microbial activity and quality change. Appl Soil Ecol 2007;36(1):32-40.

Fioretto A, Papa S, Pellegrino A, Ferrigno A. Microbial activities in soils of a Mediterranean ecosystem in different successional stages. Soil Biol Biochem 2009;41(10):2061-8.

Francaviglia R, Gataleta L, Marchionni M, Trinchera A, Aromolo R, Benedetti A, et al. Soil quality and vulnerability in a Mediterranean natural ecosystem of Central Italy. Chemosphere 2004;55(3):455-66.
Garcia C, Hernandez T, Roldan A, Martin A. Effect of plant cover decline on chemical and microbiological parameters under Mediterranean climate. Soil Biol Biochem 2002; 34(5):635-42.

Garland JL. Analysis and interpretation of community-level physiological profiles in microbial ecology. FEMS Microbiol Ecol 1997;24(4):289-300.

Gritti ES, Smith B, Sykes MT. Vulnerability of Mediterranean Basin ecosystems to climate change and invasion by exotic plant species. J Biogeogr 2006;33(6):145-57.

Iovieno P, Baath E. Effect of drying and rewetting on bacterial growth rates in soil. FEMS Microbiol Ecol 2008;65(3):400-7.

Koch. Oligotrophs versus copiotrophs. Bioessays 2001;23(4):657-61.

Kourtev PS, Ehrenfeld JG, Huang WZ. Enzyme activities during litter decomposition of two exotic and two native plant species in hardwood forests of New Jersey. Soil Biol Biochem 2002;34(9):1207-18.

Kurz C, Couteaux MM, Thiery JM. Residence time and decomposition rate of Pinus pinaster needles in a forest floor from direct field measurements under a Mediterranean climate. Soil Biol Biochem 2000;32(8-9):1197-206.

Massiot D, Fayon F, Capron M, King I, Le Calve S, Alonso B, et al. Modelling one- and twodimensional solid-state NMR spectra. Magn Reson Chem 2002;40(4):70-6.

Mathers NJ, Jalota RK, Dalal RC, Boyd SE. ${ }^{13} \mathrm{C}$-NMR analysis of decomposing litter and fine roots in the semi-arid Mulga Lands of southern Queensland. Soil Biol Biochem 2007; 39(5):993-1006.

Muhammad S, Müller T, Joergensen RG. Relationships between soil biological and other soil properties in saline and alkaline arable soils from the Pakistani Punjab. J Arid Environ 2008;72(4):448-57.

Nannipieri P, Ascher J, Ceccherini MT, Landi L, Pietramellara G, Renella G. Microbial diversity and soil functions. Eur J Soil Sci 2003;54(2):655-70.

Papa S, Pellegrino A, Fioretto A. Microbial activity and quality changes during decomposition of Quercus ilex leaf litter in three Mediterranean woods. Appl Soil Ecol 2008; 40(3):401-10.

Qasemian L, Guiral D, Ziarelli F, Ruaudel F, Farnet AM. Does anthracene affect microbial activities and organic matter decomposition? A comparative study in Pinus halepensis litters from Mediterranean coastal and inland areas. Chemosphere 2012;89(5): 548-55.

Rajaniemi TK, Allison VJ. Abiotic conditions and plant cover differentially affect microbial biomass and community composition on dune gradients. Soil Biol Biochem 2009; 41(1):102-9.

Rietz DN, Haynes RJ. Effects of irrigation-induced salinity and sodicity on soil microbial activity. Soil Biol Biochem 2003;35(6):845-54.

Rousk J, Elyaagubi FK, Jones DL, Godbold DL. Bacterial salt tolerance is unrelated to soil salinity across an arid agroecosystem salinity gradient. Soil Biol Biochem 2011; 43(2):1881-7.

Sardinha M, Mülle T, Schmeisky H, Joergensen RG. Microbial performance in soils along a salinity gradient under acidic conditions. Appl Soil Ecol 2003;23(3):237-44.

Schimel JP, Gulledge JM, Clein-Curley JS, Lindstrom JE, Braddock JF. Moisture effects on microbial activity and community structure in decomposing birch litter in the Alaskan taiga. Soil Biol Biochem 1999;31(6):831-8.

Setia R, Marschner P, Baldock J, Chittleborough D, Verma V. Relationships between carbon dioxide emission and soil properties in salt-affected landscapes. Soil Biol Biochem 2011;43(3):667-74

Sinsabaugh RL, Carreiro MM, Repert DA. Allocation of extracellular enzymatic activity in relation to litter composition, C10 deposition, and mass loss. Biogeochemistry 2002;60(9):1-24

Sommerkorn M. Micro-topographic patterns unravel controls of soil water and temperature on soil respiration in three Siberian tundra systems. Soil Biol Biochem 2008; 40(7):1792-802.

Toberman H, Freeman C, Evans C, Fenner N, Artz RRE. Summer drought decreases soil fungal diversity and associated phenol oxidase activity in upland Calluna heathland soil. FEMS Microbiol Ecol 2008;66(6):426-36.

Turner BL, Driessen JP, Haygarth PM, McKelvie ID. Potential contribution of lysed bacterial cells to phosphorus solubilisation in two rewetted Australian pasture soils. Soil Biol Biochem 2003;35(1):187-9.

Wichern J, Wichern F, Joergensen RG. Impact of salinity on soil microbial communities and the decomposition of maize in acidic soils. Geoderma 2006:137(1-2):100-8.

Yuan BC, Li ZZ, Liu H, Gao M, Zhang YY. Microbial biomass and activity in salt affected soils under arid conditions. Appl Soil Ecol 2007;35(2):319-28.

Zahran $\mathrm{HH}$. Diversity, adaptation and activity of the bacterial flora in saline environments. Biol Fertil Soils 1997;25(1):211-23.

Zhu H, Zhao C, Li J, Li Y, Wang F. Analysis of impact factors on scrubland soil respiration in the southern Gurbantunggut Desert, central Asia. Environ Geol 2008;54(4):1403-9. 